\title{
Efficiency of growing crossbreed bull-calves of the mountain cattle with Russian polled breed
}

\author{
G.A. Simonov 1 , V.S. Zoteev ${ }^{2}$, M.M. Sadykov ${ }^{3}$, P.A. Aligazieva ${ }^{4}$, and M.P. Alikhanov ${ }^{3}$ \\ ${ }^{1}$ Vologda Scientific Center of the Russian Academy of Sciences, North-Western Research Institute of \\ dairy and grassland farming, 160555, Lenin St., 14, Molochnyy rural settlement, Vologda, Russia \\ ${ }^{2}$ Samara State Agrarian University, 446442, Uchebnyy St., 1, Ust'-Kinel'skiy, Samara region, Russia \\ ${ }^{3}$ Federal Agrarian Scientific Center of the Republic of Dagestan, 367950, Makhachkala, Dagestan \\ region, Russia \\ ${ }^{4}$ Dagestan State Agrarian University, 367032, Magomed Gadzhiev St., 180, Makhachkala, Dagestan \\ region, Russia
}

\begin{abstract}
The article presents the results of cross-breeding of mountain cattle with Russian polled breed. The growth and development of the crossbreed and purebred bull-calves of these breeds in the mountainous province of Dagestan have been studied in a comparative aspect. Efficiency of highland pastures use by crossbreed animals in comparison with purebred mountain peers has been established. The young cattle was grown according to the technology of meat cattle breeding "cow - calf". In ablactation, the crossbred bull-calves had a living weight of $191.3 \mathrm{~kg}$ versus $159.3 \mathrm{~kg}$ in peers of mountain cattle. This figure was higher by $32.0 \mathrm{~kg}$ or $20.1 \%$ compared to purebred bull-calves of mountain cattle. At 12 months of age, the crossbred animals were also superior in living weight in comparison of young mountain cattle by $40.1 \mathrm{~kg}$ or $18.4 \%$. According to this indicator, the advantage in crossbred animals at 15 months of age remained. The live mass of crossbred bull-calves at 18 months of age equaled to 399.5 $\mathrm{kg}$ against $332.6 \mathrm{~kg}$ of purebred mountain peers, the difference in favor of the former was $66.9 \mathrm{~kg}$ or $20.1 \%$. Average daily growth of crossbreed bullcalves during the growing period was 122 grams or $20.8 \%$ higher. Young crossbred cattle had a clear advantage in terms of physique. Heavy carcasses with high slaughter yield were obtained from it. The conducted studies indicate the effectiveness of cross-breeding of mountain cattle with Russian polled breed in the mountainous province of Dagestan.
\end{abstract}

\section{Introduction}

Natural foraging lands are the main source of livestock production in the mountainous province of Dagestan. A rich variety of grass stand of mountain pastures allows for a summer period to significantly increase the production of livestock products and grow more than ten thousand livestock heads. Production efficiency under these conditions depends on the genetic potential of ranched cattle breeds and rational use of natural pastures.

An important condition for increasing the production of livestock products, increasing the productive qualities of animals is the organization of detailed livestock feeding [20]. It 
should be noted that the economic component also plays a large role in the conduct of cattle breeding [23]. To improve the indicators in livestock, it is necessary to have a strong feed base, which contributes to the realization of animals genetic potential, cost reduction of received products and increase profitability level [21,22].

According to medical norms, providing the population of the country with proteins of animal origin remains a priority task of agro-industrial complex and food security of Russia.

Currently, in Russia beef is produced mainly due to dairy productivity directed cattle. This trend has persisted for many years. It should be noted that the number of dairy cattle in our country is declining year after year. Therefore, in the near future the lack of breedstock replenishment will increase, which in turn will adversely affect also the fattening livestock. As a result, a shortage of beef production can be expected. Therefore, it is necessary to use all reserves in order to avoid meat production reduction.

Domestic and foreign experience shows that the problem of food security in the country cannot be solved without the accelerated development of specialized of beef cattle breeding, well adapted to natural and climatic conditions.

Therefore, under the current conditions, the development of beef cattle is of special importance. Currently, the number of beef cattle in the country is 2.26 million heads, which is $8.4 \%$ more than the level of 2017 . There is a trend of increasing the number of specialised beef cattle in the near future to 2.4 million heads.

It should be noted that Dagestan has large areas of alpine and subalpine natural pastures with high nutritional value of grass. In addition, a long grazing season in the region can contribute to the production of cheap beef.

Currently, the republic produces more than 250 thousand tons of meat in carcass weight, and mountain areas produce more than $50 \%$ of this amount due to dairy cattle and aboriginal mountain cattle. Per capita, beef is produced 2 times less than is required by medical standards. The existing beef shortage can be filled by the accelerated development of specialized beef cattle breeding, especially in the foothill and mountain provinces, where there are over 2,780 thousand hectares of alpine and subalpine meadows and pastures [2].

It should be noted that currently there are very few meat and mix bred cattle in the republic. However, it is possible to make up for the problem of beef shortage taking into account the rational use of genetic resources of domestic beef cattle $[10,12,13]$.

Mountain cattle, bred in the highlands of the republic at an altitude of 1800-2500 m above sea level, possesses such economic qualities as endurance, mobility, low susceptibility to diseases, good fertility, adaptability to grazing in harsh mountain conditions, but is characterized by late maturity and low productivity. The animals have a sturdy skeleton, a strong constitution, move easily through mountain pastures and respond well to improved feeding conditions.

The live weight of the marketable mountain cattle does not exceed $180-230 \mathrm{~kg}$, which is the result of the lack of any breeding work and extensive stockkeeping technology, as well as inaccuracy in the livestock feeding.

Activities carried out in order to increase productivity of mountain cattle do not bring a positive result, imported pure-bred animals do not adapt well in conditions of mountain province, significant withdrawal is observed, productivity of them under existing foraging and other conditions is reduced due to poor adaptability to mountainous terrain.

It should be noted that domestic meat cattle breeds are deprived of the need for acclimatization, they are unpretentious to growing conditions and have high reproduction abilities at good productivity. In this regard, there was a need for the republic to replace lowproductive, late maturity mountain cattle with more rapid-maturity animals of domestic meat breed to increase beef production.

As a promising direction in improving the productivity of beef cattle along with improving feeding and keeping conditions can be the cross-breeding of aboriginal highland, 
ranked from the main herd of dairy cows according to indicators of their low dairy yield, with bulls of Russian polled breed.

The development of beef cattle breeding in the republic needs a comprehensive approach taking into account such factors as vertical zonality of mountain pastures, creation of a strong feed base, breed selection, nucleus creation in relation to the breeding area of animals. It should be emphasized that the productivity of animals primarily depends on genotypic features and the balance of diets. Balanced diets positively affect the productivity of animals, their growth and development, health, safety, reproduction capacity, quality of products received from them, as indicated in a number of works [3-6, 8, 9, 11, 14-19] that should be taken into account when creating highly productive meat herds.

Cross-breeding cows of mountain cattle with bulls of domestic meat breeds takes on special relevance and importance in the republic to increase beef production, especially in the mountain province with large reserves of unused pastures. For this purpose we used the domestic meat breed - the Russian polled. It is characterized by high productivity, combines high adaptability to different climatic conditions with excellent meat qualities among other meat breeds in Russia [1].

The purpose of the research is to study the efficiency of growing crossbreed bull-calves obtained from crossbreeding of mountain cattle cows with bulls of Russian polled breed in the mountainous province of Dagestan in order to increase beef production.

The research objectives included:

- to study growth, development, dynamics of live weight and average daily growth of bull-calves during the growing period;

- exterior features of purebred and crossbreed animals;

- meat productivity of bull-calves

\section{Materials and methods}

Scientific and production experiment was conducted in 2018-2019 in the SFU "Shimikhyursky" of Kurakh district of the Republic of Dagestan. The object of research was purebred bull-calves of mountain cattle and crossbreed obtained from cross-breeding of mountain cattle with bulls of Russian polled breed. To achieve the set goal, two groups (control and experimental) were formed on the principle of pairs of analogues from newborn bulls of 10 heads each. The experiment was carried out according to the following scheme (Table 1).

Table 1. Experiment scheme

\begin{tabular}{|c|c|c|c|c|}
\hline \multirow{2}{*}{ Group } & \multicolumn{2}{|c|}{ Breed } & \multirow{2}{*}{ Breed and race } & \multirow{2}{*}{$\begin{array}{l}\text { Number of } \\
\text { animals per } \\
\text { group }\end{array}$} \\
\hline & father & mother & & \\
\hline Control & mountain & mountain & mountain & 10 \\
\hline Experimental & $\begin{array}{c}\text { Russian } \\
\text { polled }\end{array}$ & mountain & $\begin{array}{l}\text { Russian polled } \times \\
\text { Mountain }\end{array}$ & 10 \\
\hline
\end{tabular}

The control group consisted of purebred bull-calves of mountain cattle, and an experimental group - of crossbreed bull-calves of mountain cattle with Russian polled. The purebred bull-calves of the mountain cattle had light colour, the farmed animals had black colour, polled. Youth was grown by the technology of meat cattle breeding "cow-calf". During the suckling period, subject young animals were kept together with mothers. During the experiment, the animals of both groups were in the same conditions of keeping and feeding on subalpine pastures. 
It should be noted that during the stabling period of the subject bull-calves under suckling, they were fed up with grain feed and protein-vitamin-mineral concentrates to ensure fullfledged feeding. During the summer, they were transferred to pastoral keeping in the mountains. In our experiment, the weaning of the subjects was carried out in October at the age of 8 months. After weaning in the stabling period, they were kept under a three-wall canopy on a permanent litter. Animal feeding was carried out in a pasture feeding yard. After the ablactation of the bull-calves from their mothers at 8 months of age, they were fed according to the existing norms of the RAAS. From 15 to 18 months of age, the subject bulls were on the graziery on alpine pastures. After removal from the graziery, a control slaughter of bull-calves of 3 heads from each group according to the method of VIZh [7] was carried out. All the digital material obtained in the experiment was processed biometrically using variational statistics methods using Statistica, Statqraf software package.

\section{Results and discussion}

Interbreed differences in the living weight of subject bull-calves are given in (Table 2).

Table 2. Dynamics of live weight of bull-calves, $\mathrm{kg}$

\begin{tabular}{|c|c|c|}
\hline \multirow{2}{*}{ Age, months } & \multicolumn{2}{|c|}{ Group } \\
\cline { 2 - 3 } & control & experimental \\
\hline At birth & $16.5 \pm 0.87$ & $17.8 \pm 0.45$ \\
\hline 8 & $159.3 \pm 4.90$ & $191.3 \pm 6.00^{* *}$ \\
\hline 12 & $218.4 \pm 5.45$ & $258.5 \pm 6.35^{* * *}$ \\
\hline 15 & $273.0 \pm 5.78$ & $325.4 \pm 6.47^{* * *}$ \\
\hline 18 & $332.6 \pm 6.67$ & $399.5 \pm 7,43^{* * *}$ \\
\hline
\end{tabular}

From the analysis of Table 1 it is clear that at birth the bull-calves outperformed the analogues by $1.3 \mathrm{~kg}$ or $7.9 \%$. Growth, development and change of body weight of subject bull-calves in subsequent age periods proceeded differently depending on their breed characteristics. It should be noted that the cultivation of young animals of both groups during the experiment from birth to ablactation was done by the "cow-calf" technology with animal grazing on alpine pastures.

By ablactation from mothers at 8-month age, the crossbreed bull-calves from the Russian polled breed reached $191.3 \mathrm{~kg}$, purebred analogues of mountain cattle $-159.3 \mathrm{~kg}$. The live weight advantage of crossbreed animals was $32.0 \mathrm{~kg}$ or $20.8 \%$ compared to purebred youth.

Further observations of the living weight dynamics of subject animals indicate high growth intensity of bull-calves table.1. At 18 months of age in the conditions of the highlands, the crossbreed bull-calves had a living weight of $399.5 \mathrm{~kg}$, and their purebred peers - 332.6 $\mathrm{kg}$ respectively. The live weight advantage was in favor of crossbreed animals $-66.9 \mathrm{~kg}$ or $20.1 \%$ at $(\mathrm{P}<0.001)$.

The growth intensity of the subject bull-calves can be judged by the indicators of average daily growth (Table 3).

Table 3. Average daily growth of bull-calves, $g$

\begin{tabular}{|c|c|c|}
\hline \multirow{2}{*}{ Age, months } & \multicolumn{2}{|c|}{ Group } \\
\cline { 2 - 3 } & control & experimental \\
\hline 8 & $595 \pm 21$ & $723 \pm 33^{* * *}$ \\
\hline 12 & $492 \pm 14$ & $560 \pm 22 * *$ \\
\hline
\end{tabular}




\begin{tabular}{|c|c|c|}
\hline 15 & $607 \pm 18$ & $743 \pm 27 * * *$ \\
\hline 18 & $662 \pm 16$ & $823 \pm 23 * * *$ \\
\hline $0-18$ & 585 & 707 \\
\hline \% to control & 100 & 120.8 \\
\hline
\end{tabular}

$* * \mathrm{P} \leq 0.01 ; * * * \mathrm{P} \leq 0.001$

Table 3 shows that during the period of youth growth according to the beef cattle husbandry technology from birth to 8 months the difference was in favour of crossbreed bull-calves $-128 \mathrm{~g}$ or $21.5 \%$ at $(\mathrm{P}<0.001)$. After weaning, average daily increases went down, aided by ablactation from the mothers and insufficient foraging base. Under conditions of full-fledged feeding in the pasture period, the subject animals had high growth energy, the average daily increase of crossbreed bull-calves amounted to $823 \mathrm{~g}$, analogues of mountain cattle - $662 \mathrm{~g}$, advantage in favor of crossbreed bull-calves was $161 \mathrm{~g}$ or $24.3 \%$. For the entire growing period, the average daily increase of crossbreed bull-calves was higher by $20.8 \%$ compared to purebred peers.

During the period of experiment, linear growth of the subjects was studied by taking measurements of physique.

At 8 months of age, crossbreed bull-calves had differences in comparison to the animals of the control group. At this age, the experimental group of animals were superior in all measurements to the peers of the control group. At 12 months of age, the crossbreed bullcalves had a clear superiority over the peers of mountain cattle in all latitudinal measurements. A similar pattern can be traced over the entire period of experimental animals growth. It should be noted that the crossbreed exceeded the analogues of the control group in chest width by $-10.1 \%$, chest depth $-9.4 \%$, chest girth $-17.3 \%$, width in ribbing by $3.0 \%$. The differences in measures remained at 15 months of age between groups. At 18 months of age, crossbreed bull-calves exceeded purebred peers from the control group by: in chest width - $11.2 \%$, chest depth $-11.5 \%$, chest girth - $16.3 \%$, and width in ribbing $-11.1 \%$. The crossbreed young cattle was superior to the animals of the control group in altitudinal measurements as well, it was distinguished by elongated torso and the best meat forms, which it inherited from the paternal Russian polled breed.

For the complete characterization of linear growth, the indices of physique in age aspect were determined (Table 4).

Table 4. Bull-calves physique indices, $\%$

\begin{tabular}{|c|c|c|c|c|c|c|c|c|}
\hline \multirow{4}{*}{ Index } & \multicolumn{8}{|c|}{ Group } \\
\hline & \multicolumn{4}{|c|}{ control } & \multicolumn{4}{|c|}{ Experimental } \\
\hline & \multicolumn{8}{|c|}{ Age, months } \\
\hline & 8 & 12 & 15 & 18 & 8 & 12 & 15 & 18 \\
\hline Legginess & 54.4 & 52.6 & 50.8 & 50.1 & 51.5 & 51.2 & 49.9 & 49.7 \\
\hline Lengthiness & 102.8 & 107.8 & 110.3 & 112.5 & 107.3 & 112.0 & 115.0 & 121.8 \\
\hline Chest & 61.3 & 60.4 & 61.5 & 62.0 & 62.6 & 61.9 & 63.2 & 64.2 \\
\hline Overgrowth & 103.3 & 103.3 & 102.7 & 101.5 & 102.1 & 101.6 & 102.0 & 101.7 \\
\hline Blockiness & 114.8 & 108.4 & 113.4 & 113.0 & 108.1 & 117.6 & 116.0 & 114.7 \\
\hline Boneness & 11.5 & 12.2 & 12.8 & 13.2 & 12.0 & 12.7 & 13.9 & 15.2 \\
\hline $\begin{array}{l}\text { Pelvic- } \\
\text { thoracic }\end{array}$ & 96.6 & 93.6 & 94.5 & 90.7 & 96.7 & 96.2 & 95.3 & 93.6 \\
\hline Massiveness & 107.2 & 117.1 & 125.2 & 129.7 & 118.3 & 129.1 & 133.3 & 136.7 \\
\hline
\end{tabular}

By analyzing the data of table 4, there are certain differences in age in the index of lengthiness, thoracic, blockiness. Thus, the index of legginess in the crossbreed bull-calves amounted to $48.9 \%$, the peers of the control group $-50.1 \%$, which indicates the late maturity 
of the bull-calves of the mountain cattle. Crossbreed bull-calves outperformed analogues on the index of lengthiness by $-9.3 \%$, blockiness by $1.7 \%$, massiveness by $7.0 \%$.

Meat productivity of animals was studied by control slaughter of young animals. It was found that in both groups there were high rates of meat productivity (Table 5).

Table 5. Slaughter qualities of bull-calves

\begin{tabular}{|c|c|c|}
\hline \multirow{2}{*}{ Indicator } & \multicolumn{2}{|c|}{ Group } \\
\cline { 2 - 3 } & control & experimental \\
\hline Wg & $332.6 \pm 8.65$ & $399.5 \pm 7.47^{* * *}$ \\
\hline Preslaughter live weight, $\mathrm{kg}$ & $316.4 \pm 5.93$ & $380.7 \pm 6.78^{* * *}$ \\
\hline Weight of carcass, kg & $166.4 \pm 4.81$ & $210.0 \pm 3.57^{* *}$ \\
\hline Carcass yield, \% & 52.6 & 55.4 \\
\hline Weight of internal fat, kg & $6.7 \pm 0.63$ & $9.5 \pm 0.42^{* *}$ \\
\hline Inner fat yield, \% & 2.1 & 2.5 \\
\hline Slaughter weight, kg & $173.1 \pm 3.55$ & $219.5 \pm 4.16^{* * *}$ \\
\hline Slaughter yield, \% & 54.7 & 57.6 \\
\hline Skin weight, $\mathrm{kg}$ & $22.4 \pm 3.2$ & $29.6 \pm 2.6^{*}$ \\
\hline Skin yield, $\%$ & 7.1 & 7.8 \\
\hline
\end{tabular}

${ }^{*} \mathrm{P}<0.05,{ }^{* *} \mathrm{P}<0.01,{ }^{* * *} \mathrm{P}<0.001$

Table 5 shows that the crossbreed animals at slaughter gave heavy carcasses with good wetting and high slaughter yield. In terms of the slaughterwarm carcass weight, the crossbreed exceeded the analogues by $43.6 \mathrm{~kg}$ or $26.2 \%$, with the advantage of the carcass yield by $2.8 \%$. Slaughter yield at bull-calves of the experimental group was $57.6 \%$, at control $-54.7 \%$ respectively. The advantage on this indicator was in favor of the crossbreed animals $-2.9 \%$. From crossbreed bull-calves, heavy skins with weight of $29.6 \mathrm{~kg}$ were obtained, from purebred $-22.4 \mathrm{~kg}$, with an advantage of $7.2 \mathrm{~kg}$ or $32.1 \%$ in favor of crossbreed.

During the experiment, the morphological composition of bull-calves' carcasses were studied (Table 6).

Table 6. Morphological composition of bull-calves' carcasses

\begin{tabular}{|c|c|c|}
\hline \multirow{2}{*}{ Indicator } & \multicolumn{2}{|c|}{ croup } \\
\cline { 2 - 3 } & control & experimental \\
\hline Weight of chilled carcass, $\mathrm{kg}$ & $164.9 \pm 5.6$ & $208.2 \pm 4.3^{* *}$ \\
\hline Weight of boneless meat, kg & $125.7 \pm 4.2$ & $164.3 \pm 5.3^{* *}$ \\
\hline Boneless meat yield, \% & 76.2 & 78.9 \\
\hline Weight of bones, kg & 36.0 & 40.4 \\
\hline Bone yield, \% & 22.0 & 19.4 \\
\hline Cartilage and tendons, kg & 3.2 & 2.5 \\
\hline Cartilage and tendons yield, \\
$\% \quad$ Fleshing Index & 2.5 & 4.07 \\
\hline $\begin{array}{l}\text { Boneless meat yield per 100 } \\
\mathrm{kg} \text { of pre-slaughter live weight, } \\
\mathrm{kg}\end{array}$ & 3.49 & 43.1 \\
\hline
\end{tabular}

$$
* * \mathrm{P}<0.01
$$

From the analysis of table 6 it is clear that the crossbreed animals differed from the analogues of the control group by large boneless meat yield, the difference in favor of the 
crossbreed was $38.6 \mathrm{~kg}$ or $30.7 \%$. Bone yield in the carcasses of crossbreed bull-calves was less by $2.6 \%$ compared to purebred animals. They had an advantage on the beefiness index and boneless meat yield on pre-slaughter live weight by $3.4 \mathrm{~kg}$ or $8.6 \%$.

The results of our studies show some differences in chemical composition in the average boneless meat sample (Table 7).

Table 7. Chemical composition of average bull-calves meat sample, $\%$

\begin{tabular}{|c|c|c|c|c|c|}
\hline Group & Moisture & $\begin{array}{c}\text { Dry } \\
\text { matter }\end{array}$ & Protein & Fat & Ash \\
\hline I & $74.87 \pm 1.32$ & $25.13 \pm 1.39$ & $19.75 \pm 0.84$ & $4.41 \pm 0.82$ & $0.97 \pm 0.04$ \\
\hline II & $73.65 \pm 0.27$ & $26.35 \pm 0.75$ & $20.17 \pm 0.84$ & $5.23 \pm 0.47$ & $0.95 \pm 0.03$ \\
\hline
\end{tabular}

Table 7 shows that the highest content of dry matter was in the meat of the crossbreed bull-calves compared to the purebred peers. Crossbreed animals exceeded purebred peers of mountain cattle in the content of dry matter meat by $1.22 \%$, protein $-0.42 \%$, fat by $0.82 \%$.

\section{Conclusions}

Thus, studies have shown that cross-breeding of ranked mountain cows with bulls of Russian polled breed in the mountainous province of Dagestan allows to obtain crossbreed animals with high growth intensity. When withdrawn from fattening at 18 months of age, the animals have a live weight advantage of $66.9 \mathrm{~kg}$ or $20.1 \%$ compared to purebred peers. The average daily increase in growing in crossbreed bull-calves is $20.8 \%$ higher, carcasses are characterized by higher slaughter yield and the amount of boneless meat in them. Crossbreeding animals in mountain conditions will increase meat production and improve its quality in the Republic of Dagestan.

\section{References}

1. H.A. Amerkhanov, et al., Zootechnics, 4, 2-3 (2008)

2. M.A. Balamirzoev, et al., Soils of Dagestan: ecological aspects of their rational use, 70114 (Dagknigoizdat, Makhachkala, 2008)

3. P.A. Aligazieva, et al., Problems of AIC development of the region, 18 (2 (18)), 58-61 (2014)

4. D. Gayirbegov, et al., Combined fodder, 12, 63-64 (2015)

5. V.S. Zoteev, et al., Livestock, 5, 45-46 (1985)

6. A.P. Kalashnikov, et al., Reports of the All-Union Academy of Agricultural Sciences named after V.I. Lenin, 11, 29 (1984)

7. Ed. D.L. Levantin, Methodical recommendations on the study of meat productivity and quality of cattle meat, 54 (Dubrovytsy, 1977)

8. M. Magomedov, et al., Dairy and meat cattle breeding, 1, 11 (1993)

9. M.Sh. Magomedov, P.A. Aligazieva, Complete feeds, 10, 63-64 (2013)

10. M.Sh. Magomedov, et al., Dairy and meat cattle breeding, 1, 13-15 (2016)

11. M.M. Sadykov, et al., Problems of development of agro-industrial complex of the region, 24 (4 (24)), 63-66 (2015)

12. M.M. Sadykov, et al., Dairy and meat cattle breeding, 7, 23-25 (2016)

13. M.M. Sadykov, et al., Problems of development of agro-industrial complex of the region, 31 (3 (31)), 63-67 (2017)

14. G.A. Simonov, Zootechnics, 12, 30-34 (1988)

15. G.A. Simonov, Herald of the Russian Academy of Agricultural Sciences, 3, 60-61 (1988)

16. G.A. Simonov, P.A. Aligazieva, Advice to dairy cattle farmer, (Makhachkala, 2011) 
17. S. Tyapugin, D. Gayirbegov, A. Fedin, et al., Dairy and meat cattle breeding, 4, 19-21 (2011)

18. E.A. Tyapugin, et al., Reports of the Russian Academy of Agricultural Sciences, 3, 50$53(2015)$

19. A.T. Varakin, D.K. Kulik, V.V. Salomatin, V.S. Zoteev, G.A. Simonov, International Journal of Innovative Technology and Exploring Engineering, 9 (1), 3837-3841 (2019)

20. I.F. Gorlov, V.I. Levakhin, V.F Radchikov, V.F. Tsai, S.E. Bozhkova, Modern Applied Science, 9 (10), 8-16 (2015)

21. V.S. Zoteev, E.I. Pisarev, S.I. Nikolaev, V.V. Salomatin, A.T. Varakin, Research Journal of Pharmaceutical, Biological and Chemical Sciences, 9 (5), 1422-1428 (2018)

22. S.A. Miroshnikov, E.V. Yausheva, E.A. Sizova, E.P. Miroshnikova, V.I. Levahin, Oriental Journal of Chemistry, 31 (4), 2327-2336 (2015)

23. A.M. Uhtverov, Kh.B. Baymishev, I.N. Khakimov, M.A. Kohanov, V.S. Grigoryev, A.T. Varakin, Research Journal of Pharmaceutical, Biological and Chemical Sciences, 9 (5), 935-942 (2018) 